Acta vet. scand. $1977,18,1-9$.

From the Small Animal Clinic, Royal Veterinary and Agricultural University, Copenhagen, Denmark.

\title{
FELINE PANLEUKOPAENIA VIRUS AND MINK ENTERITIS VIRUS*
}

\section{A SEROLOGICAL STUDY}

\author{
By
}

\section{A. Flagstad}

FLAGSTAD, A.: Feline panleukopaenia virus and mink enteritis virus. A serological study. Acta vet. scand. $1977,18,1-9 . \quad$ - The serological relationship of Danish feline panleukopaenia virus and mink enteritis virus and strains from Great Britain, USA, Germany and Canada was examined in neutralization tests using a direct immunofluorescence technique. Vaccine strains of the virus were used representing virus strains from the different countries. It was found that all Danish feline panleukopaenia virus strains and the mink enteritis strain belong to the same serotype and further that they are of similar antigenicity as feline panleukopaenia virus strains and mink enteritis strains isolated in other countries.

feline panleukopaenia virus; mink enteritis virus; serological comparison.

The serological relationship between different feline panleukopaenia strains has been studied by Johnson (1967) and by Scott et al. (1970) indicating that all strains tested belong to the same serotype. Immunological relationship between feline panleukopaenia virus (FPV) and mink enteritis virus (MEV) has been demonstrated in vivo in vaccination experiments by Wills (1952) and Wills \& Belcher (1956) and in in vitro neutralization tests by Johnson $(1967,1971)$.

Isolation of feline panleukopaenia virus in Denmark has been described previously (Flagstad 1973). In a subsequent study it was demonstrated that the multiplication of the virus depends on the degree of mitotic activity in cell cultures. It was further

* This investigation was supported by grants from the Danish Agricultural and Veterinary Research Council. 
found that the cytopathic effect and the presence of intranuclear inclusion bodies were of a transient nature (Flagstad 1975).

The aim of the present work was to examine by use of neutralization tests the serological relationship between the feline panleukopaenia virus and the mink enteritis virus isolated in Denmark and furthermore to study the serological relationship between these Danish strains and strains from other parts of the world.

\section{MATERIALS AND METHODS}

Virus and vaccines

a) Danish feline panleukopaenia culture virus strains (90, 12231, AG 1, AG 2, AG 3, A 1113, A 1188, A 855, A 992) (Flagstad 1973). Virus titres ranged from $10^{2.5}$ to $10^{4.5} \mathrm{TCID} 50 / \mathrm{ml}$.

b) A Danish mink enteritis culture virus strain with a titre of $10^{3.5} \mathrm{TCID} 50 / \mathrm{ml}$. The mink enteritis virus was isolated from faeces and jejunum taken at necropsy from a virus enteritis-infected mink. The technique used for isolation of the virus was the same as previously described for isolation of feline panleukopaenia virus (Flagstad 1973). The third cell culture passage of the isolation from faeces was used (DMEV).

c) A live freeze-dried tissue culture attenuated feline panleukopaenia virus vaccine (Philips-Roxane). This vaccine strain was propagated in cell culture and had a titre of $10^{4.5} \mathrm{TCID} 50 / \mathrm{ml}$ after three passages.

Virus preparations were stored at $-20^{\circ} \mathrm{C}$ prior to use.

d) A formalin-inactivated feline panleukopaenia vaccine (Behringwerke) prepared from organ specimens of cats inoculated with feline panleukopaenia virus.

e) A formalin-inactivated feline panleukopaenia vaccine (Connaught) prepared from organs of mink inoculated with mink enteritis virus.

f) A formalin-inactivated mink enteritis vaccine (Connaught) prepared from organs of mink inoculated with mink enteritis virus.

\section{Cell cultures and inoculation procedure}

Secondary kitten kidney cells seeded in Leighton tubes with about 1 mill. cells per ml were used as described by Flagstad (1975). One hundred i.u. G-penicillin and $100 \mu \mathrm{g}$ dihydrostreptomycin were used per $100 \mathrm{ml}$ medium. 
Inoculation of the virus was carried out about $4 \mathrm{hrs}$. after seeding of the cells when cell growth was ascertained by microscopical examination.

\section{Sera}

a) A British feline panleukopaenia post-challenge serum*.

b) Antisera were prepared in rabbits against one Danish feline panleukopaenia virus (90), the Danish mink enteritis virus (DMEV), one vaccine from the Behringwerke, and two vaccines from the Connaught. The rabbits were initially injected intravenously with $4 \mathrm{ml}$ culture virus or subcutaneously with $1 \mathrm{ml}$ of the inactivated vaccine virus, and this was repeated on days 2,4 , 8, 12 and 42. Blood samples were drawn after the last injection. c) Antiserum against the feline panleukopaenia virus strains (90) was also prepared in a cat by intraperitoneal inoculation with $1 \mathrm{ml}$ of the virus (titre $10^{4.5} \mathrm{TCID} 50 / \mathrm{ml}$ ). The cat was anaesthetized and bled four weeks after inoculation. After immunization this serum had a titre of 1:5120 against the feline panleukopaenia virus. This serum was used for preparation of fluorescein-conjugated globulin.

Sera were stored at $-20^{\circ} \mathrm{C}$ prior to use.

\section{Preparation of fluorescein-conjugated antiserum}

The gamma globulin fraction was obtained from serum as described by Nairn (1969) and conjugated with fluorescein isothiocyanate (FITC) according to the method described by Flagstad \& Eriksen (1974). The conjugate was stored at $-20^{\circ} \mathrm{C}$ and diluted 1:20 in borate buffered saline when used ${ }^{\star \star}$.

\section{Neutralization test}

The direct fluorescent antibody technique (FAT) was employed as indicator system in the serum neutralization test. A twofold serial dilution of test serum starting at $1: 5$ was prepared. Equal volumes of culture virus diluted to contain $100-200 \mathrm{flu}-$

* The British serum was received from Dr. K. J. O’Réilly, The Wellcome Research Laboratories.

** The preparation of the conjugates was kindly carried out at the Institute of Internal Medicine, Royal Veterinary and Agricultural University. 
orescent cell infective doses 50 (FCID50) were added to each serum dilution. The resultant mixtures were incubated at $37^{\circ} \mathrm{C}$ for $1 \mathrm{hr}$. Two Leighton tubes were inoculated with $0.2 \mathrm{ml}$ of each dilution. Tenfold dilutions of control virus were prepared, and $0.1 \mathrm{ml}$ of each dilution was inoculated into two Leighton tubes to verify the quantity of virus present in each neutralization system.

Uninoculated cultures were used as cell culture controls.

\section{Staining and examination of the cell cultures}

The cultures were fixed in acetone at room temperature for 5 min. or more. The fixed cultures on the cover slips were stained with the conjugate in a moist chamber, washed five times in Nairn phosphate buffered saline for $3 \mathrm{~min}$. each, and mounted on slides with a solution of glycerol buffered to $\mathrm{pH}$ 7.2. The slides were then examined in a Nikon microscope at $100 \times$ and $250 \times$, using an iodine quartz lamp and interference filter as primary, and OG 4 as secondary filter (Rygaard \& Olsen 1971).

Serological comparison of feline panleukopaenia virus and mink enteritis virus

Neutralization tests were made between the Danish feline panleukopaenia virus strains (90, 12231, AG 1, AG 2, AG 3, A 1113, A 1188, A 855, A 992) and antiserum against one of these strains (90). Neutralization tests were carried out with the Danish feline panleukopaenia virus strain 90 and the vaccine strain from Philips-Roxane using antiserum to the Danish strain 90. Furthermore the Danish feline panleukopaenia virus strain 90 and the Danish mink enteritis virus strain (DMEV) were examined in neutralization tests using antisera to the following: Strain 90, strain DMEV, the vaccines from Behringwerke and Connaught. A British post-challenge serum was also used. After three days' incubation at $37^{\circ} \mathrm{C}$ the cover slips were stained with the conjugated globulin for identification of viral antigen. Slides showing nuclear fluorescence were regarded negative for neutralization and slides without fluorescence positive for neutralization. The serum neutralization titre was expressed as the highest serum dilution which inhibited the FITC staining. 


\section{RESULTS}

Serological comparison of feline panleukopaenia virus and mink enteritis virus

While neutralizing antibodies were not present in preinoculation sera, the rabbit sera had titres from 1:40 to 1:1280 after immunization.

Using the neutralization test, all feline panleukopaenia virus strains so far recovered in Denmark (Flagstad 1973) were found to be of the same serotype, and the vaccine strain of feline panleukopaenia virus from Philips-Roxane was found to be of the same serotype as the virus isolated in Denmark (Table 1).

T a b l e 1. Cross-neutralization test between different feline panleukopaenia virus strains and antiserum.

\begin{tabular}{lc}
\hline Virus strain & $\begin{array}{c}\text { Antiserum against feline } \\
\text { panleukopaenia strain } 90\end{array}$ \\
\hline Feline panleukopaenia & \\
strain 90 & $1: 1280$ \\
12231 & $1: 1280$ \\
AG 1 & $1: 1280$ \\
AG 2 & $1: 1280$ \\
AG 3 & $1: 1280$ \\
A 1113 & $1: 1280$ \\
A 1188 & $1: 2560$ \\
A 855 & $1: 1280$ \\
A 992 & $1: 2560$ \\
Philips-Roxane vaccine virus & $1: 1280$ \\
\hline
\end{tabular}

In cross-neutralization tests between feline panleukopaenia virus and mink enteritis virus there was complete cross-neutralization of the rabbit sera in all cases (Table 2).

Feline panleukopaenia immune serum from Great Britain neutralized the Danish strain (90) of feline panleukopaenia virus and the Danish strain of mink enteritis virus (Table 2).

\section{DISCUSSION}

Neutralization tests indicated that all Danish feline panleukopaenia and mink enteritis strains belong to the same serotype and that they are of similar antigenic structure as feline panleukopaenia virus strains and mink enteritis strains isolated in 
T a b l e 2. Cross-neutralization between viruses of feline panleukopaenia and mink enteritis.

\begin{tabular}{|c|c|c|c|c|c|c|}
\hline \multirow[b]{2}{*}{ Virus strain } & \multicolumn{6}{|c|}{ Antiserum against } \\
\hline & $\begin{array}{c}\text { feline panleu- } \\
\text { kopaenia } \\
\text { strain }^{\star}\end{array}$ & $\begin{array}{l}\text { mink enteri- } \\
\text { tis strain } \\
\text { DMEV }\end{array}$ & $\begin{array}{l}\text { i- vacc. Con- } \\
\text { naught } \\
\text { mink enteritis } \\
\text { strain }\end{array}$ & $\begin{array}{l}\text { vacc. Beh- } \\
\text { ringwerke } \\
\text { feline } \\
\text { panleuko- } \\
\text { paenia strain }\end{array}$ & $\begin{array}{l}\text { vacc. mink } \\
\text { enteritis } \\
\text { Connaught }\end{array}$ & $\begin{array}{c}\text { British } \\
\text { feline panleu- } \\
\text { kopaenia strain }\end{array}$ \\
\hline
\end{tabular}

$\begin{array}{lcccccc}\begin{array}{l}\text { feline pan- } \\ \text { leukopaenia } \\ \text { strain 90 }\end{array} & 1: 1280 & 1: 1280 & 1: 160 & 1: 640 & 1: 40 & 1: 1280 \\ \begin{array}{l}\text { mink enteri- } \\ \text { tis strain }\end{array} & 1: 1280 & 1: 1280 & 1: 160 & 1: 640 & 1: 40 & 1: 1280 \\ \text { DMEV } & & & & & & \end{array}$

* Feline panleukopaenia virus strain 90 antiserum showed similar titre of neutralizing antibodies when tested against eight other Danish strains as well as the Philips-Roxane vaccine strain of feline panleukopaenia virus.

Great Britain, Germany, USA and Canada. This is in agreement with findings of Scott et al. (1970), who found only serotype of feline panleukopaenia virus strains, and with Johnson (1967, 1971), who demonstrated a close antigenic relationship between feline panleukopaenia virus strains and mink enteritis strains. The results described in the present report may suggest a closer antigenic relationship of feline panleukopaenia strains and mink enteritis strains than found by Johnson (1967). A possible explanation of this discrepancy might be that the cultures used in the present study were secondary cell cultures. Johnson (1967) used young partly complete primary cell cultures, which may have resulted in a variation in the titres obtained. Secondary cell cultures were used since it was previously found (Flagstad 1975) that they grew more uniformly than primary cells and that the in vitro examination of feline panleukopaenia virus consequently could be carried out with regularity. The sensitivity of the neutralization test using different techniques has been discussed by Csiza (1971).

Staining of cell cultures with FITC conjugated panleukopaenia antiserum seems to be highly specific. Specific fluorescence of the nucleus of infected cells was seen both in cultures inoculated with feline panleukopaenia virus and in those inoculated with mink enteritis virus (Fig. 1). There was a distinct 


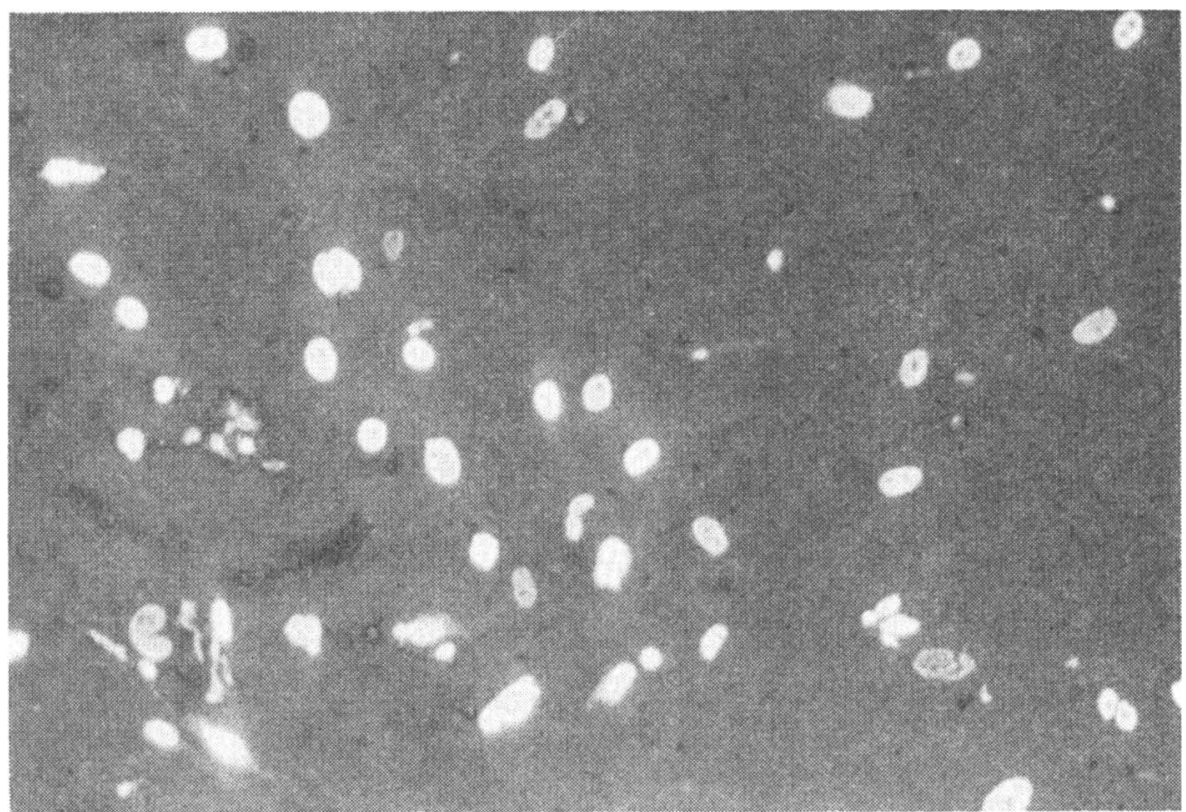

Fig u r e 1. Feline kidney cell culture three days after inoculation. Fluorescein isothiocyanate stain. (Magnification $\times 160$ ).

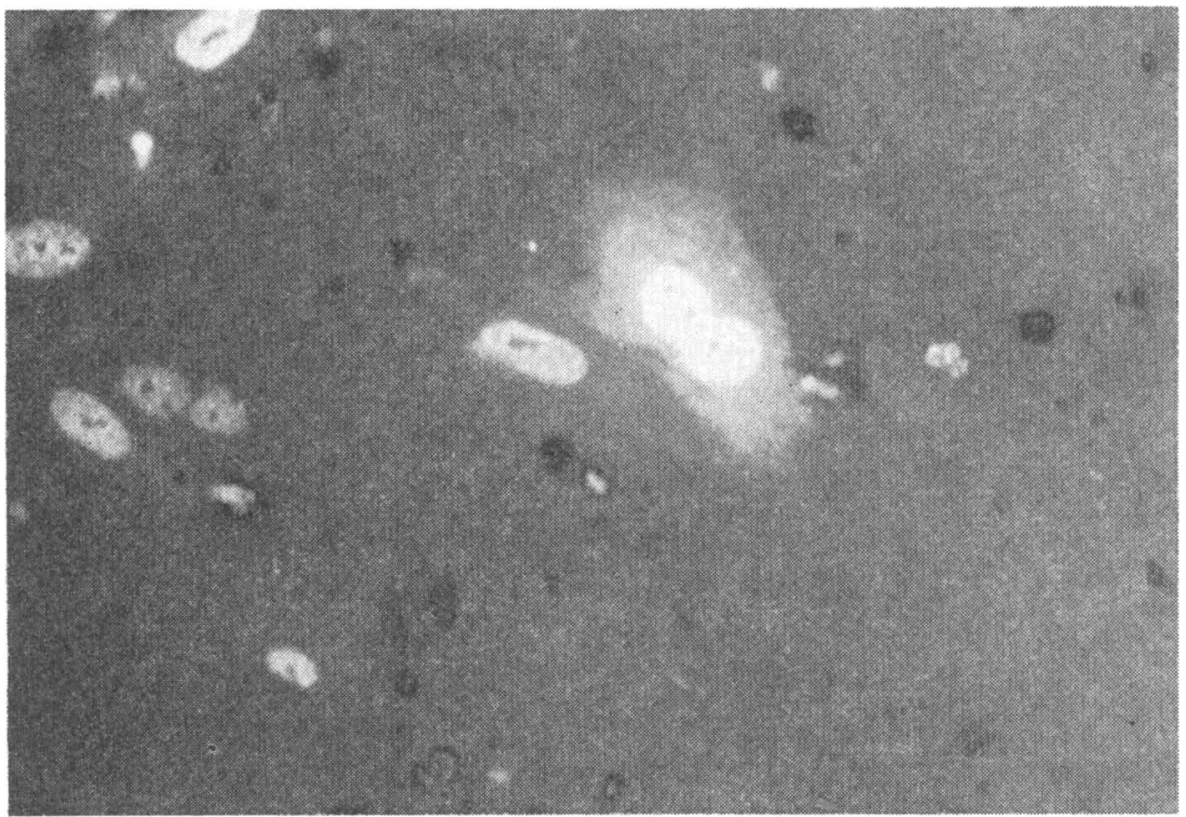

F i g u r e 2. Feline kidney cell culture, three days after inoculation. Fluorescein isothiocyanate stain. (Magnification $\times 320$ ). 
fluorescence of the nucleus, and in some cells also a faint fluorescence of the cytoplasma could be seen (Fig. 2). The fluorescent cells were very distinct against a dark background of non-fluorescent cells and were easily detected even in preparations with only few infected cells. The uninoculated control cultures did not show fluorescence. Furthermore, in neutralization tests using a serum without antibodies against panleukopaenia virus, fluorescent staining was seen, while this was inhibited when a serum with antibodies was used.

In immunofluorescence studies of feline panleukopaenia in neutralization tests King \& Croghan (1965) described a narrow band of fluorescence at the periphery of the inclusion and the perinuclear region. Fastier (1968) as in the present study found fluorescent inclusion bodies.

The neutralization test can be used as an aid in the clinical differential diagnosis to other diseases of cat and mink. The use of the test for this purpose, though, is limited by the fact that three days are required to obtain a result and further that repeated examination of possible increases in titre is nesessary. However, the neutralization test can be used in epidemiological investigations of feline panleukopaenia and mink enteritis for instance in search for subclinical disease.

\section{REFERENCES}

Cisza, $K$. C.: Comments on serologic procedures in the study of feline panleukopaenia. J. Amer. vet. med. Ass. 1971, 158, 884-887.

Fastier, L. B.: Feline panleukopenia - A serological study. Vet. Rec. $1968,83,653-655$.

Flagstad, A.: A study on in vitro isolation of feline panleukopaenia virus. Acta path. microbiol. scand. 1973, 81, 385-392.

Flagstad, A.: Studies on the growth of feline panleukopaenia virus in cell cultures. Acta path. microbiol. scand. 1975, 83, 71-78.

Flagstad, T. \& L. Eriksen: Hepatic immunoglobulin synthesis in fasciola hepatica infected calves. Res. Vet. Sci. 1974, 17, 59-63.

Johnson, R. H.: Feline panleukopaenia virus in vitro comparison of strains with a mink enteritis virus. J. small Animal Pract. 1967, $8,319-324$.

Johnson, R. H.: Serologic procedures for the study of feline panleukopaenia. J. Amer. vet. med. Ass. 1971, 158, 876-883.

King, D. A. \& D. L. Croghan: Immunofluorescence of feline panleucopenia virus in cell culture. Determination of immunological status of felines by serum neutralization. Canad. J. comp. Med. $1965,29,85-89$. 
Nairn, R. C.: Fluorescent Protein Tracing. E. \& S. Livingstone, Edinburgh and London 1969, 303.

Rygaard, J. \& W. Olsen: Toward quantitation of exitation. Ann. N. Y. Acad. Sci. 1971, 177, 410—413.

Scott, F., C. K. Csiza \& J. H. Gillespie: Feline viruses. V. Serum neutralization test for feline panleukopenia. Cornell Vet. 1970, 60, $183-192$.

Wills, G.: Notes on infectious enteritis of mink and its relationship to feline enteritis. Canad. J. comp. Med. 1952, 16, 419-420.

Wills, G. \& J. Belcher: The prevention of virus enteritis of mink with commercial feline panleucopenia vaccine. J. Amer. vet. med. Ass. 1956, 138, 559-560.

\section{SAMMENDRAG}

Feline Panleukopaenia virus og mink enteritis virus. En serologisk undersøgelse.

Den serologiske forbindelse mellem dansk kattesygevirus (Feline panleukopaenia virus), dansk mink enteritis virus og stammer af disse fra USA, Tyskland, England og Canada er unders $\emptyset$ gt ved neutralisationstest. Direkte immunofluorescens teknik er brugt til unders $\emptyset$ gelserne. Alle danske feline panleukopaenia virus stammer og mink enteritis stammer fandtes at være af samme serotype og var af samme antigene struktur som feline panleukopaenia stammer og mink enteritis virus stammer isoleret $i$ andre lande.

(Received June 16, 1976).

Reprints may be requested from: A. Flagstad, the Small Animal Clinic, Royal Veterinary and Agricultural University, Bülowsvej 13, DK-1870 Copenhagen V, Denmark. 